\title{
Minimizing Wildfire Risk With Grazing
}

\section{Reducing fuel load with tools like proper grazing can help mitigate wildfire devastation.}

\author{
By Travis Brown, Representing the Northern Great Plains SRM Section
}

Lightning cracked across the sky like veins on the back of your hand.

It reached a fiery finger out, as if in reprimand, And torched a crippled evergreen that leaned against the sky,

While grass and sagebrush hunkered down that hellish hot July.

The tall pine tree exploded, and shot its flaming seeds, Like comets into kerosene, igniting all the weeds.

The air was thick as dog's breath when the fire's feet hit the ground,

It licked its pyrogenic lips, and then it looked around!

It offered up no quarter, and burned for seven days, A hundred thousand acres consumed within the blaze.

Brave men came out to kill it, cutting trail after trail But it jumped their puny firebreaks, and scattered 'em like quail.

It was ugly from a distance, and uglier up close, So said the men who saw the greasy belly of the ghost. It made 'em cry for Mama! Blistered paint on D-8 Cats! It sucked the sweat right off their backs and broke their thermostats!

Unless you've lived through a fire, (like the one Baxter Black describes in his poem) it's difficult to imagine this kind of sheer power and carnage. Montana lived through a summer of fires like that in 2000 , and in the aftermath of that devastation we find ourselves asking: Why did it happen? Will it happen again? And, maybe most importantly, what can we do to improve resource management and prevent a natural event like fire from creating such devastation?

There seems little question that better management can play a big role.
Improved range management is one area where we should focus. Allow me to explain some ways that range scientists are anxious to be involved in the solution to this huge challenge.

By August 2000, Montana was in the grip of the $12^{\text {th }}$ hottest and $18^{\text {th }}$ driest summer on record. Forests were tinder dry, clogged with dead and dying trees, with an enormous fuel load, and the problem wasn't just in Montana.

The U.S. Forest Service, manager of over 190 million acres of America's land; said that 56 million acres were considered to be at high risk for catastrophic fire.

Even a General Accounting Office report stated the nation's forests were in poor health; that tree stands have grown denser, with increases in insect and disease infestation. The report went on to say these forests posed an immediate problem, the threat of disastrous wildfires! Just four months later, that threat became reality, in the most destructive fire season in decades

Most experts agree there are two main reasons why our forests had such a dangerous fuel load. First, an excellent job of fire prevention and suppression by the U.S. Forest Service over the past 90 years had prevented natural burning, leaving dead, dry timber and fuel to accumulate year after year. Smokey Bear was effective....all too effective!

Second, reductions in logging, and grazing, had reduced our ability to manage forests by selectively removing trees, thinning stands, and harvesting the grass and brush that provides fuel.

By summer's end, 82,000 wildfires had burned up nearly 7 million acres of land across America. We are talking about an area the size of the states of Rhode Island, Connecticut, Delaware, and half of New Jersey added together! The impact was devastating:

- people's livelihoods were ruined, 
- fish and wildlife habitat was destroyed,

- old growth forest was lost,

- livestock and wildlife died, and winter range was destroyed,

- range improvements were lost, including hundreds of miles of fence and water development projects,

- soils were eroded,.water polluted,..

- and enough timber burned, to build three and a half million homes!

\section{Managing To Avoid Fires}

The good news is that today, from the crucible of that summer's fires, is emerging a new philosophy for managing our national forests. Range scientists were heartened, when former Montana Governor Marc Racicot said, "The wild fire disaster of this summer presents a golden opportunity to change the entire legal framework that regulates management of the national forests."

One such plan is to fight fire with fire, by using smaller, carefully controlled fires that burn along the ground and kill the small brush and saplings, but spare the big trees whose bark is inches thick. Ideally such a cooler, less devastating, ground fire would sweep away the excess fuel every $8-12$ years.

Range resource managers like John Twitchell with the Colorado State Forest Department knows that livestock grazing can also play a big role. He writes that properly managed grazing can be an effective means of reducing fuel load, and stimulating range production.

Another plan is to follow the leadership of states such as Arizona and use tree thinning to reduce the density of trees, to mimic natural conditions. In parts of the west, there are a thousand trees per acre today, in the same places where the earliest pioneer journals only recorded a dozen per acre. With management, thinning, harvesting, and a carefully controlled burning program, we can slowly reduce the risk of severe wildfire and disease, the first step in ecosystem restoration.

In a letter to the head of the Forest Service and the Bureau of Land Management, the President of the National Cattlemen's Beef Association, George Hall said: "Proper livestock grazing is one of the most effective, and least expensive, methods of fuel management. When coupled with controlled burns, grazing can reduce the occurrence and the impact of catastrophic wildfire."

Further, the Chief of Range Management Research, for the Southern Forest Experiment Station in Louisiana, R. S. Campbell, explained how livestock grazing measurably reduces fire hazard by removing and breaking up potential fuel, citing research that moderate grazing removed 44 percent of herbage on experimental range in southern Georgia.

And yet there are those who still say, "Leave the forest alone! Stop the logging! End the grazing!" Well, what if we just do nothing?

Benjamin Stout, Retired Dean of the University of
Montana School of Forestry points out, and I quote: "If we stop managing National Forests, they will decline and die, just as they have done 16 times since the last Ice Age. As they move toward death, they consume less carbon dioxide, which means more air pollution and maybe more global warming."

The answer? Stout says: "Management..periodic harvesting followed by long periods of regrowth and renewal. This is the only known tool", he says, "for arresting the inevitable decline in forests. What's more, using wood we harvest, we can store carbon indefinitely, and prevent it's return to the atmosphere."

In summary, it seems there are several resource management tools that we can use to prevent, or at least mitigate forest fire disasters like the summer of 2000. Selective tree thinning, carefully controlled burning, and proper grazing management can make a big difference.

But we cannot wait! Because the problem gets worse every season. We cannot allow those who would stop all management, to simply let nature take it's course.

Because that course will not be pretty. Nor would it be responsible, and it would be very costly in loss of property, damage to environment, and even in human lives.

Mother nature has sent us a warning, like a wisp of smoke on a distant horizon. Whether we heed that warning is up to us!

Travis Brown's paper earned first place in the High School Youth Forum competition held at the 2002 SRM Annual Meeting in Kansas City.

\section{References}

Booth, William, Washington Post, (2000, September 26), reprinted in the Billings Gazette, pg 1, 12 .

Cobb, Mike, (2000, October), The Explorer, Lewis \& Clark Conservation District newsletter, pg 4.

Dodder, Joanna, (2001, May 30) The Daily Courier, pg 1-2, "Prescott Arizona Official work on Circle of Protection"

Falstad, Jan, (2000, October 17) Billings Gazette, pg 1,8

Hall, George, (2000, August 15) National Cattlemen's Beef Association Press Release, "Grazing is an Effective Long-Term Solution for Fire Management."

Loftus, Bill, (2001 January), Logging Selectively, University of Idaho College of Agriculture Field Guide, pg 1-2.

Mader, T. R., (2000, September/October issue) Abundant Wildlife newsletter, pg 1-2.

Petersen, James, Evergreen Magazine, (2000 winter) Vol. 10, No. 21, pg 4-5, 13-17, 30

Seely, Ron, (2000, October 15) Billings Gazette, pg 1, 10.

Twitchell, John (2001), Colorado State University, Colorado State Forest Home Page,

http://lamar.colostate.edu/ statefor/grazing.htm

U.S.D.A. Forest Service, Northern Region, The Extent and Effects of the Fires of 2000 - A Preliminary Assessment, pg 2060. 